\title{
Leniency Program to Prove the Cartel in the Enforcement of Business Competition Law
}

\author{
Muhammad Zulfadli $^{1} \quad$ Ahmadi Miru $^{2} \quad$ Anwar Borahima $^{2} \quad$ Winner Sitorus $^{3}$ \\ 1.Graduate School, Hasanuddin University, Indonesia \\ 2.Professor, Faculty of Law, Hasanuddin University, Indonesia \\ 3.Associate Professor, Faculty of Law, Hasanuddin University, Indonesia
}

\begin{abstract}
The strongest characteristic of the cartel is the nature of the confidentiality of the agreement. Because confidentiality makes proof very difficult. The difficulty of proving a cartel case is due to the limited authority of the KPPU in carrying out its duties. In connection with the difficulty in expressing the cartel, business competition authorities in several countries such as the United States, Japan, Australia and countries that are members of the European Union have implemented punitive relief programs. the main purpose of implementing a sentence relief program. The purpose of implementing a penalty relief program is for cartel actors to report their violations to competition authorities; giving a cold effect that prevents the formation of a cartel; and to obtain further information (evidence) regarding the existence of a cartel. Therefore, the implementation of a penalty relief program in business competition law in Indonesia is very urgent. Implementation of a penalty relief program will be effective if there is a strong legal basis in business competition law. Further suggestions to the Government and Parliament of the Republic of Indonesia need to amend Law No. 5 of 1999 by regulating provisions in a comprehensive manner regarding the sentence relief program.
\end{abstract}

Keyword: cartel, law enforcement, leniency program.

DOI: $10.7176 / \mathrm{JLPG} / 87-14$

Publication date:July $31^{\text {st }} 2019$

\section{Introduction}

One form of abuse of business actors' freedom is by carrying out cartel practices, which are realized in the form of agreements, both written and oral. Cartel is an anti-competitive behavior that creates losses for competition and consumers.

The cartel was perceived as the most dangerous form of anti-competitive action because the perpetrators agreed to do a conspiracy regarding the main matters in business activities. The cartel is very dangerous because it can determine a very high price level or amount of production, causing direct losses to consumers because prices rise significantly and goods or services in the market become limited. ${ }^{1}$

The characteristics of the most powerful cartel are the nature of the confidentiality of the agreement. Because confidentiality makes proof very difficult. This is indicated by the minimal number of cartel cases that can be revealed by KPPU. The difficulty of proof of a cartel case is due to the limitations regarding the KPPU's authority in carrying out its duties, among others: ${ }^{2}$

a. KPPU is not authorized to conduct searches on business actors suspected of violating the Law No. 5 Year 1999;

b. The confidentiality of business actors so that KPPU cannot then obtain data on business actors needed for investigative purposes;

c. The good collaboration between KPPU and the government has not yet been established in terms of providing alleged unfair business competition, thus causing KPPU to have difficulty in performing its duties due to lack of supporting data;

d. KPPU cannot force the presence of business actors or witnesses to be examined, even though the KPPU has the authority to call him.

In connection with the difficulty of disclosing cartels, business competition authorities in several countries such as the United States, Japan, Australia and countries belonging to the European Union have implemented leniency programs. ${ }^{3}$ In their jurisdiction to disclose the case of the cartel, and also aim to obtain initial information regarding the formation of a cartel. In its implementation, the program's leniency is proven to be successful. In the European Union, 24 of the 27 EU member countries have implemented leniency programs

\footnotetext{
${ }^{1}$ Komisi Pengawas Persaingan Usaha, Peraturan KPPU No. 4 Year 2012, about Implementation Guidelines Article 11 concerning Cartel Based on Law No. 5 Year 1999.

${ }^{2}$ Riris Munadiya, Bukti Tidak Langsung (Indirect Evidence) dalam Penanganan Kasus Persaingan Usaha, Jurnal Persaingan Usaha, Year 2011, p. 12

${ }^{3}$ Program Leniency is legal immunity or legal relief that can be received by individuals, company employees, or companies that first provide information related to cartel practices.
} 
since $1996 .^{1}$

Leniency program adalah "a system, publicy announced, of, partial or total exoneration from the penalties that would otherwise be applicable to a cartel membership to a competition (law) enforcement agency ${ }^{2}$. leniency program is legal immunity or legal relief that can be received by individuals, company employees, or companies that first provide information related to cartel practices. The concept of leniency program is almost the same as the concept of Justice Collaborator in the criminal law of corruption, where the perpetrator acknowledges the mistake and is willing to provide information as a witness.

An effective Leniency program will encourage cartel members to give recognition of their involvement in the cartel to the competition authorities, even before the investigation phase begins. In some cases of investigations in the United States, the leniency program also encouraged cartel members to leave the cartel, report to the government, and provide evidence of other cartel members. ${ }^{3}$

As applied in the United States and the European Union, Indonesia has submitted a leniency program in the Draft Law (Bill) to amend the Law No. 5 Year 1999 concerning Prohibition of Monopolistic Practices and Unfair Business Competition (Law No. 5 Year 1999), which has been registered in the national legislation program since 2017. The program's Leniency was proposed because the Business Competition Supervisory Commission (KPPU) as a business competition supervisory institution in Indonesia has limited resources in disclosing cartel cases. ${ }^{4}$ In Article 74 of the Bill on Amendments to Law No. 5 Year 1999 regulates (1) KPPU can provide forgiveness and/or reduction of penalties for business actors who admit and/or report their actions that are suspected of violating Article 4, Article 5, Article 6, Article 7, Article 8, Article 9, Article 10, Article 11, Article 12, Article 13, Article 14, Article 21; (2) Forgiveness and/or reduction of penalties as referred to in Paragraph (1) shall be regulated in KPPU regulations.

Submission of leniency programs in the Bill on Law Amendments No. 5 Year 1999, also to avoid inconsistencies in the application of indirect evidence as evidence, and aim to obtain direct evidence in cartel cases. Some of the KPPU's decisions in cartel cases that used indirect evidence were canceled by the Supreme Court on the grounds that indirect evidence was not known in Indonesian law. This provision is very good, but more detailed and clear arrangements must be arranged in accordance with the conditions and culture of the Indonesian nation, considering several factors such as risk factors, political factors, time factors, legal certainty, confidentiality factors, and socialization factors. Requirements and procedures are needed to regulate explicitly and explicitly leniency programs in Indonesia after providing a legal basis for leniency programs through amendments to Law No. 5 Year 1999. Important provisions cover the authority of KPPU; proof; and sanctions; so that the leniency program has the attraction and provides a deterrent effect for the cartel business actor. Based on the empirical facts as mentioned above, the problems that will be discussed in this paper are how are the principles of leniency programs in business competition law? and how is the urgency of implementing a leniency program in business competition procedural law in Indonesia?

\section{Research Method}

This type of research is normative legal research ${ }^{5}$ with a statute approach and a conceptual approach. ${ }^{6}$ The data used are secondary data collected through documentation. The collected data is then analyzed qualitatively.

\section{Results and Discussion}

Jimly Asshiddiqie explained that law enforcement was interpreted as an effort made to make law, both from a narrow formal meaning and in a broad material sense, as a code of conduct in every legal act, both by legal subjects concerned and by an official law enforcement apparatus given the duty and authority by law to guarantee the functioning of legal norms that apply in the life of society and the state. ${ }^{7}$ Satjipto Rahardjo stated that law enforcement is an attempt to realize ideas about legal certainty, social benefits and justice into reality. The process of realizing these ideas is the essence of law enforcement. ${ }^{8}$

In order for law enforcement to run effectively, according to Soerjono Soekanto is influenced by several factors, namely legal factors, law enforcement factors, factors supporting facilities or facilities, and cultural factors of society. ${ }^{9}$ Legal factors are related to the substance of legal material, namely the material contained in

\footnotetext{
${ }^{1}$ Anna Maria Tri Anggraini, Program Leniency dalam Mengungkap Kartel Menurut Hukum Persaingan Usaha, Jurnal Persaingan Usaha, Year 2011, p. 107

${ }^{2}$ United Nations Confrence on Trade and Development (UNCTAD), The Use of Leniency Program as a Tool for The Enforcement of Competition Law Against Hardcore Cartels in Developing Countries

${ }^{3}$ Scott D. Hammod, US Department of Justice, Cornerstones of an Effective Leniency Program, 2004, p 1. Downloaded April 1, 2018

${ }^{4}$ Website of the House of Representatives, dpr.go.id. accessed 10 October 2018.

${ }^{5}$ Soerjono Soekanto and Sri Mamudji, Penelitian Hukum Normatif; Suatu Tinjauan Singkat, Rajawali Press, Jakarta. 2004, p. 13-14

${ }^{6}$ Peter Mahmud Marzuki, 2005, Penelitian Hukum, Prenadamedia Group Jakarta, p. 35

${ }^{7}$ Jimly Asshiddiqie, "Makalah Penegak Hukum"

${ }^{8}$ Raharjo Satjipto, 1987, Masalah Penegakan Hukum, Alumni, Bandung, p. 15

${ }^{9}$ Soerjono Soekanto, 2004, Faktor-Faktor yang Mempengaruhi Penegakan Hukum, Raja Grafindo Persada, Jakarta, p. 19.
} 
laws and regulations, including laws. The factors of this legislation can be an obstacle in law enforcement if, for example, the principles of the enactment of the law are not followed, there are no implementing regulations needed to implement the law, there is a lack of clarity in the meaning of the law resulting in multiple interpretations and the incompleteness of the substance of the law itself. ${ }^{1}$

Law Enforcement Papers Mark Furse from the University of Glasgow, UK, states that there is no legitimacy to justify such behavior. Mark further explained that OECD countries already have a strict definition of 'hard core cartel', namely as "..anticompetitive agreement by competitors to fix prices, restrict output, submit collusive tender, or divide or share markets."

Today there are several cartel handling models known in the world, such as;

1) Civil/administrative exlusive models (used in several European Union and China);

2) Mixed administrative and criminal models (USA and UK)

3) Leniency ${ }^{2}$

The cartel can include many behaviors such as regulation of production, horizontal pricing, tender collusion, division of territory, distribution of consumers, and distribution of market share. The characteristics of the cartel include the conspiracy between business people, the use of associations, the distribution of information to members, the involvement of senior executives, the existence of compensation mechanisms for cartel members, and the implementation of pricing. Provisions related to the cartel in Law No. 5 Year 1999 refers to Articles 5, 7, 9, 10, 11, 12, 22, and 24. To prove the cartel, KPPU has so far applied evidence evidence, in the form of economic analysis (structural behavior) and communication. Cartel agreement in the Act. No. 5 of 1999 was formulated with the rule of reason method, it can be interpreted that business actors can make agreements with competing business actors who intend to influence prices by regulating the production or marketing of goods or services provided they do not result in monopolistic practices and unfair business competition.

The cartel is one of the strategies implemented by businesses to be able to influence prices by regulating the amount of their production. ${ }^{3}$ Cartel practice is common in markets with an oligopoly structure where there are only a few business actors with a dominant market share. This situation caused quite fierce competition in the market. The actors compete with each other to get consumers' attention in various ways, for example giving discounts, improving service and quality of goods, massive promotions, and so on. Paripurna Sugarda believes that cartel practices in Indonesia are caused by several factors, namely:

1) There is a large percentage of assets that are controlled by a small percentage of business actors;

2) Control of business actors in parliament and executives through political parties is still quite large;

3) The existence of a conglomerate system including vertical integration and market share control;

4) Markets with an oligopolistic structure;

5) Difficulty in proving because the applicable regulations are inadequate;

6) The authority of the KPPU is still limited. ${ }^{4}$

Therefore, Paripurna recommends for: First, strengthen political will in eradicating cartels; Second, amendments to Law No. 5 Year 1999, by expanding prohibited acts, not limited to agreements; Third, strengthen the authority of the KPPU. ${ }^{5}$

\section{A. The Concept of Leniency Program in Business Competition Law}

Leniency is defined as a reduction in penalties for business actors, who collaborate with competition authorities by disclosing information on the existence of a cartel before the investigation begins, or by providing additional information that can speed up the investigation. At first glance this concept has similarities with the whistle blower concept in criminal law, or justice collaborator in disclosing corruption cases.

Therefore, observations of several principles, such as, Clarity, certainty, and confidentiality, can make their functions more useful and useful. Indeed, many authorities complaining about their jurisdiction lacking clarity, certainty, and confidentiality under the rules of leniency in one jurisdiction can prevent a party from being involved in using a leniency program for the other party, thus the positive effects of the program. ${ }^{6}$ The new thing about the antitrust leniency program, according to Spagnolo, is that the characteristics that make leniency programs in antitrust special, apart from the new things in the intended law enforcement, are their ex ante, general and social conditions. ${ }^{7}$ The exemption programs are said to be ex ante because, in their main and most innovative parts, they are addressed to perpetrators who have not been identified, encouraging them to voluntarily confess. Therefore the leniency policy acts before the detection and stage of prosecution, not only when detection occurs and prosecution is carried out, as an offer of application.

\footnotetext{
${ }^{1}$ Ibid,

${ }^{2}$ The Cartel Offence: "Great for a headline but not much else"? European Competition Law Review, 32(5), p. 223-230

${ }^{3}$ Ibid., p. 114

${ }^{4}$ Paripurna Sugarda, delivered at the Seminar "Kartel: Kendala dan Solusi Penegakan Hukumnya" on May 10, 2017 at Fakultas Hukum UGM Yogyakarta.

${ }^{5}$ Ibid.

${ }^{6}$ Ibid.

${ }^{7}$ Giancarlo Spagnolo, Handbook of Antitrust Ekonomics, Amerika: MIT Press, 2008, p. 262
} 
Human security is not as narrow as the editorial, because the meaning includes a variety of security dimensions, such as economic security, food security, health security, environmental security, personal security, community security, and political security. ${ }^{1}$ Program Leniency is called general in that they complain anonymously to anyone who is definitely included in the situation and applies or can think to potentially apply in a way. ${ }^{2}$ Leniency programs are called social in terms of even in America, where with the prosecutor's discretion, it is always permissible to exchange forgiveness against evidence, they take the form of codification, automatic (but predictable), and policies can be advertised in general. There are at least three main objectives that business competition authorities want to achieve through the application of leniency programs, as follows: ${ }^{3}$

1) to encourage cartel actors to report their violations to competition authorities;

2) in the long term, leniency program arrangements are expected to provide a deterrent effect that prevents the formation of cartels;

3) to get more information (evidence) about the whereabouts of the cartel and therefore reduce the costs of law enforcement and prosecution.

Leniency programs are implemented to destabilize a cartel. Business actors who intend to carry out cartels will find it difficult to trust each other, because the business actor who first leaked his conspiracy will be forgiven while the others will be punished. With the lack of trust between business actors to enter into a cartel agreement, the actual cartel agreement will never be effective. ${ }^{4}$ At the same time, the leniency program also hinders certain anti-competitive and collaborative activities among companies that know that enough with the photographer to come to the authority to bring down all the companies involved. ${ }^{5}$

The important thing about leniency programs is how to build a leniency program that can cause business people to come and voluntarily report their participation in the cartel that previously disappeared undetected. As discussed, the leniency program achieves rejection by creating a risk that violators will be known to their own conspiracy partners. The prospect of demolition is the most dangerous thing for cartel members because the conspiracy partners usually have access to evidence of involvement in which any leak from a single conspiracy partner can lead to an acceleration of punishment for other cartel members. Therefore, leniency programs damage the necessary elements of unity which make a cartel be operational and confidential, namely trust. ${ }^{6}$ Program Leniency will create doubt in the game of collusion, where the cartel agreement will not be the desired equilibrium result.

Leniency programs form relatively new characteristics in the enforcement of competition law and are expected to be able to erase the trust formed between cartel actors. As understood, trust is the main element of every conspiracy. A similar approach has been used successfully in efforts to prosecute the mafia, which is known as a witness protection program. All types of leniency programs must contain the following important elements: ${ }^{7}$

a. the reporting cartel actor must provide sufficient evidence about the violations committed by other cartel actors to the business competition authority;

b. the reporting cartel actor acts as a witness and accepts the waiver as agreed before, which can be in the form of a reduction in fines, a reduction in prison terms, and even a reward; and

c. Reporting cartel actors get protection against punishments or retaliatory actions that may be imposed by other cartel actors.

Leniency Program has been applied by various jurisdictions in the world and has different characteristics from one another, which cannot be separated from competition law as the policy of each country. A successful leniency program design actually has several advantages, namely emphasizing predictability, transparency, and a consistent implementation process. ${ }^{8}$

The program Leniency was initiated by the United States in 1973 and began to have a lot of impact after the revision of the Corporate Leniency Program in $1993 .{ }^{9}$ The authorities that enforce competition law are given to the Department of Justice-Antitrust Division (DOJ-AD) and Free Trade Commission (FTC). The two authorities are responsible for enforcing business competition law and can file civil proceedings and only the DOJ-AD has the authority to make criminal charges for violators. ${ }^{10}$

\footnotetext{
${ }^{1}$ Kadarudin, Human Security in International Law Perspective, Awang Long Law Review, Vol. I No. 1, November 2019, p. 37

${ }^{2}$ Ibid.

${ }^{3}$ Sjoerd Arlman, "Crime But no Punishment: An Empirical Study of the EU"s 1996 Leniency Notice and Cartel Fines in Article 81

Proceedings" (Master Thesis Universiteit van Amsterdam, Amsterdam, 2005), p. 14-15

${ }^{4}$ Erman Rajagukguk, Butir-butir Hukum Ekonomi, Jakarta; Lembaga Studi Hukum dan Ekonomi, 2011, p. 56

${ }^{5}$ Ibid., p. 10-11

${ }^{6}$ Ibid., p. 11

${ }^{7}$ Evgenia Motchenkova dan Daniel Leliefeld, “Adverse Effects of Corporate Leniency Programs in View of Industry Asymetry”, Journal of Aplied Economic Science, Vol. V, Issue (2)/12, Summer 2010, p. 114-115.

8 Ibid., p. 118

${ }^{9}$ United Nations Conference on Trade and Development (UNCTAD) MENA Programme, Competition Guidelines: Leniency Programmes, $\mathrm{p}$. 1

${ }^{10}$ Leonard W Weiss and Alynn D. Strickland, Regulation: A Case Approach, Ed. 2, New York: Mcgraw, Inc, 1982 p. 17 in Ar Miftahur
} 
In addition to the United States, Australia also implements leniency programs in their competition law system. Like the United States, Australia regulates the provision of leniency programs outside of its business competition laws, namely Competition and Consumer Act 2010 (CCA 2010). The leniency program arrangements in Australia have undergone several changes since they were implemented in 2002. Now the leniency program in Australia is regulated in the commission regulation, namely ACCC Immunity and Cooperation Policy for Cartel Conduct 2014. ${ }^{1}$

While the leniency policy arrangements in Japan were carried out through an Antimonopoly Law amendment in 2005. Based on the arrangements in the Antimonopoly Law and Criminal Accusation Policy, Japan recognized several types of leniency that could be in the form of exemptions from administrative fines, reduced administrative fines, and exemptions from possible criminal charges, as described below. ${ }^{2}$

\section{B. The Urgency of Implementing Leniency Programs in Indonesia}

The difficulty of proving a cartel agreement, especially in Indonesia, is believed to be because business people are in an oligopoly market and collude in secret. KPPU in 2010 issued very new guidelines relating to the cartel by adopting a program that had long been implemented in other developed countries, namely the leniency program. However, the Program Leniency issued by KPPU in 2010 in the form of guidelines, has obstacles to its implementation related to the underlying legal basis.

Since the KPPU does not have the authority to issue regulations that can regulate rights and obligations, the provisions regarding leniency must be complied with in the amendments to the Act. No. 5 Year 1999. The provisions will contain and regulate matters relating to leniency, which includes;

a. Definition of leniency policy; leniency policy is a policy that provides forgiveness to business actors who complain about cartel practices to KPPU.

b. The institution authorized to provide it; Law No. 5 Year 1999 only gives the authority to impose administrative actions on KPPU.

c. The subjects who received it; In accordance with the provisions of the Law No. 5 Year 1999, business actors were the recipient subjects of leniency in Indonesia.

d. Requirements for granting leniency

e. Cancellation of leniency

As discussed, the leniency program is given automatically with the fulfillment of the requirements that will be stipulated in the law. However, KPPU still has the authority to cancel the unconditional matter in the event that the applicant does not keep his promise, both to provide decisive evidence and to work together during the KPPU's investigation.

Based on the aforementioned descriptions, and bearing in mind that the leniency program policy provides the possibility of the form of exemption or reduction of sanctions for cartel offenders, the arrangement must be contained in the law, namely by amending Law No. 5 Year 1999. Regulation in the law is the strongest alternative, although it still contains weaknesses. Procedures for amending the law tend to be long and winding, and require expensive fees. The process of making or amending laws in the House of Representative of the Republic of Indonesia is also full of interests. The number of political parties with diverse interests, coupled with business actors who often have an interest in the substance of the article is a real condition that must be passed in amending a law. ${ }^{3}$

To ensure that cartel actors will choose to apply for leniency as their dominant strategy, administrative sanctions for cartel violations must also be exacerbated. This is important to ensure two things. First, these sanctions can provide sufficient sentencing effects so that they are not only valued as cost of doing business for cartel actors. Second, to increase aspects of mistrust among conspirators and increase incentives for cartel actors to betray the cartel and give its recognition.

\section{Conclusion}

Based on the description, it can be concluded that the principles of leniency programs in effective business competition law include at least three things, namely: First, clarity; Both certainty, and Third, confidentiality. Furthermore, there is the main objective of implementing the leniency program. (1) encourage cartel actors to report their violations to competition authorities; (2) provide a deterrent effect that prevents the formation of a cartel; and (3) to obtain more information (evidence) regarding the whereabouts of the cartel and thereby reduce the costs of law enforcement and prosecution. Therefore, the application of leniency programs in business competition law in Indonesia has been urgent. The implementation of the leniency program will be effective if

Rachman, Leneincy Program sebagai Upaya Memberantas Kartel dalam Hukum Persaingan Usaha di Indonesia. Jurnal Business Law Review Vol. III, 2011.

${ }^{1}$ ACCC, Discusion Paper: Review of The ACCC's Leniency Policy For Cartel Conduct, p. 3

${ }^{2}$ Antimonopoly Law of Japan, Article, 7-2, paragraph 10, items I dan Japan Fair Trade Commission, Criminal Accusation Policy, section 2.

3 Fajri Nursyamsi, et.al., Catatan Kinerja DPR 2016 Legislasi; Aspirasi atau Transaksi, Pusat Studi Hukum dan Kebijakan Indonesia, Jakarta, 2017, p. 31 
there is a strong legal basis in the business competition law. Further advice to the Government and Parliament of the Republic of Indonesia needs to amend Law No. 5 Year 1999 by regulating the provisions comprehensively regarding the leniency program.

\section{References}

ACCC, Discusion Paper: Review of The ACCC's Leniency Policy For Cartel Conduct.

Andi Fahmi Lubis, 2017, Hukum Persaingan Usaha; Antara Teks dan Konteks, KPPU, Jakarta.

Andreas Mundt President of the Bundeskartellamt, Website the Bundeskartellamt, accessed on January 15, 2019.

Anna Maria Tri Anggraini, Program Leniency dalam Mengungkap Kartel Menurut Hukum Persaingan Usaha, Jurnal Persaingan Usaha, Year 2011.

Antimonopoly Law of Japan, dan Japan Fair Trade Commission, Criminal Accusation Policy, section 2.

Ar Miftahur Rachman, Leneincy Program sebagai Upaya Memberantas Kartel dalam Hukum Persaingan Usaha di Indonesia. Jurnal Business Law Review Vol. III, 2011.

Burgerlijk Wetboek (KUH Perdata)

Cindy Nova, 2011, Kajian Yuridis Mengenai Leniency Programs sebagai Salah Satu Instrumen Mengungkap Kartel, Tesis Fakultas Hukum Univeristas Indonesia, Jakarta.

Erman Rajagukguk, 2011, Butir-butir Hukum Ekonomi, Lembaga Studi Hukum dan Ekonomi. Jakarta.

Evgenia Motchenkova and Daniel Leliefeld, "Adverse Effects of Corporate Leniency Programs In View Of Industry Asymetry”, Journal of Aplied Economic Science, Vol. V, Issue (2)/12, Summer 2010.

Fajri Nursyamsi, et.al., 2017, Catatan Kinerja DPR 2016 Legislasi; Aspirasi atau Transaksi, Pusat Studi Hukum dan Kebijakan Indonesia, Jakarta.

Giancarlo Spagnolo, 2008, Handbook of Antitrust Ekonomics, Amerika: MIT Press.

Kadarudin, Human Security in International Law Perspective, Awang Long Law Review, Vol. I No. 1, November 2019.

Law Number 5 Year 1999 concerning Prohibition of Monopolistic Practices and Unfair Business Competition

Paripurna Sugarda, delivered at the Seminar "Kartel: Kendala dan Solusi Penegakan Hukumnya" on May 10, 2017 at Fakultas Hukum UGM Yogyakarta.

Peraturan Komisi Pengawas Persaingan Usaha KPPU No. 4 Year 2012, about Implementation Guidelines Article 11 concerning Cartel Based on Law No. 5 Year 1999.

Rachmadi Usman, 2004, Kartel dan Problematikanya, PT Gramedia Pustaka, Jakarta.

Raharjo Satjipto, 1987, Masalah Penegakan Hukum, Alumni, Bandung.

Riris Munadiya, Bukti Tidak Langsung (Indirect Evidence) dalam Penanganan Kasus Persaingan Usaha, Jurnal Persaingan Usaha, Year 2011.

Scott D. Hammod, 2004, US Department of Justice, Cornerstones of an Effective Leniency Program, downloaded April 1, 2019.

Sjoerd Arlman, 2005 “Crime But no Punishment: An Empirical Study of the EU"es 1996 Leniency Notice and Cartel Fines in Article 81 Proceedings" Master Thesis Universiteit van Amsterdam, Amsterdam.

Soerjono Soekanto, 2004, Faktor-Faktor yang Mempengaruhi Penegakan Hukum, Raja Grafindo Persada, Jakarta.

Stephen F. Ross, 1993, Principles of Antitrust Law, Westbury, New York: The Foundation Press, New York.

The Cartel Offence: "Great for a headline but not much else"? European Competition Law Review.

Udin Silalahi and Rayendra L. Tobing, 2007, Perusahaan Saling Mematikan dan Bersekongkol, Elex Media Komputindo, Jakarta.

United Nations Confrence on Trade and Development (UNCTAD), The Use of Leniency Program as a Tool For The Enforcement of Competition Law Against Hardcore Cartels in Developing Countries.

Website of the House of Representatives, dpr.go.id. accessed 10 October 2018. 